\title{
Evaluation of The Potential of Amaranth Flour for Lactic Acid Fermentation
}

\author{
Z. Matejčeková*, D. Liptáková and L'. Valík
}

\begin{abstract}
Department of Nutrition and Food Assessment, Faculty of Chemical and Food Technology, Slovak University of Technology in Bratislava, Radlinského 9, SK-812 37 Bratislava, Slovak Republic
\end{abstract}

\begin{abstract}
Although cereals and pseudocereals are deficient in some basic components, fermentation process is the most economical and simple way, how to improve nutritional value, functional qualities and sensory properties of the final products. In our study, we focused on the evaluation of amaranth flour for preparation of new probiotic functional foods suitable for celiac patients. That is why the growth dynamics of several Lactobacillus sp. in amaranth mashes were evaluated. All the monitored strains showed sufficient growth in mashes (growth rates of lactobacilli ranged from 0.73 to $1.52 \mathrm{~h}^{-1}$ ). Based on the rates, only Lb. rhamnosus VT1 was able to grow with the values higher than $1.38 \mathrm{~h}^{-1}$ in both milk and water based mashes.

In the second part of our study, we described behaviour of $L b$. rhamnosus GG in amaranth water- or milk- based mashes after $8 \mathrm{~h}$ of co-cultivation with Fresco DVS 1010 culture $\left(37 \pm 1{ }^{\circ} \mathrm{C}, 5 \% \mathrm{CO}_{2}\right)$. Final counts after the fermentation reached values $10^{8} \mathrm{CFU} \cdot \mathrm{ml}^{-1}$ and no decrease was recorded during 2-week storage period at $6 \pm 1{ }^{\circ} \mathrm{C}$. Thus we may conclude that densities of lactobacilli were able to maintain above the limit of $>10^{6} \mathrm{CFU}$. $\mathrm{ml}^{-1}$ essential from the legislation point of view.
\end{abstract}

Keywords: Amaranth, pseudocereal substrates, probiotics, lactic acid bacteria, celiac disease.

\section{INTRODUCTION}

Lactic acid bacteria (LAB) are defined as a large group of heterogeneous, gram-positive, catalasenegative, non-sporeforming cocci or rods, producing lactic acid as a major catabolic product of fermentable carbohydrates. The representative species of LAB are predominantly Lactobacillus, Lactococcus, Pediococcus and Leuconostoc [1]. LAB are used not only as starter cultures for fermentation of different types of substrates, but also in beverage production and in manufacture of medicaments [2]. Probiotics are single or mixed cultures of live lactic acid bacteria that are associated with beneficial health effects on human being, play important role in managing of intestinal disorders, such as lactose intolerance, constipation, or inflammatory bowel diseases, and may have a significant role in immunological functions [3]. There are many requirements in the selection of suitable probiotic strain. A key factor is its ability to survive acidic environment of the final fermented products and the adverse conditions of the gastrointestinal tract. Survival of probiotic strain during gastrointestinal transit is also important when probiotics have to overcome low $\mathrm{pH}$ values, enzymes, bile acids and low surface tension $[4,5]$. Most probiotic foods on market are dairy based, however recent studies have been focused on non-

*Address correspondence to this author at the Department of Nutrition and Food Assessment, Faculty of Chemical and Food Technology, Slovak University of Technology in Bratislava, Radlinského 9, SK-812 37 Bratislava, Slovak Republic; E-mail: zuzana.matejcekova@stuba.sk

ISSN: 2223-3806 / E-ISSN: 1927-5951/16 dairy variant of probiotic fermented cereal and pseudocereal products [6]. Natural fermentation of cereals by lactic acid bacteria brings a wide range of benefits, including extension of shelf life, decreasing in the level of non-digestible poly- and oligosaccharides or carbohydrates and provides optimum $\mathrm{pH}$ conditions for enzymatic degradation of phytate that may increase the amount of soluble iron, calcium and zinc [7]. Lactic acid bacteria also improve organoleptic quality - taste and flavour of final products by producing alcohols, organic acids or carbonyl substances [8]. Products such as sake, cereal beer, and spirits are known all over the world and new types of fermented cereal foods are continuously being developed [6]. As described above, there is a considerable potential in manufacturing fermented functional products for specific groups of consumers that are cereals based. The main aim of this work was to evaluate important growth characteristics of selected lactic acid bacteria in amaranth substrates. Remaining of viable probiotic bacteria in final products is important since products may be consumed refrigerated after several weeks of storage. Thus, final amaranth products were therefore stored and analysed for viable cell counts of probiotic strain Lb. rhamnosus GG.

\section{MATERIALS AND METHODS}

\section{Microorganisms, Inoculation and Cultivation Conditions}

Fresco DVS 1010 culture (consists of Lactococcus lactis spp. lactis, L. lactis spp. cremoris, Streptococcus 
thermophilus) and Lactobacillus acidophilus 145 are commercial cultures from Christian and Hansen (Hørsholm, Denmark).

The probiotic strain $L b$. rhamnosus $G G$ was provided by Dr. Salminen and Ouwehand (University of Turku, Finland) and was through mediation of $\mathrm{Dr}$. Lauková (State Veterinary and Food Institute, Košice, Slovakia).

Potentially probiotic strain Lb. rhamnosus VT1, isolated from tartar sauce, from the microbial collection of Institute of Chemical Technology (Prague, Czech Republic), was provided for this study by doc. Ing. M. Plocková, PhD.

Strain Lb. paracasei subsp. paracasei was obtained from the collection of strains of Masaryk University (Brno, Czech Republic).

Fresco DVS 1010 culture was kept in a deepfreezer. Pure cultures of lactobacilli were maintained in MRS broth (Biokar Diagnostics, Beauvais, France) at 5 $\pm 1^{\circ} \mathrm{C}$

The starter culture was prepared from a $24 \mathrm{~h}$ culture of selected strain of lactobacilli grown in MRS broth at $37 \pm 1{ }^{\circ} \mathrm{C}\left(5 \% \mathrm{CO}_{2}\right)$. The standard suspension of Fresco culture was prepared from a $24 \mathrm{~h}$ culture grown in M17 broth (Biokar Diagnostics, Beauvais, France) and was incubated at $30^{\circ} \mathrm{C}$. $24 \mathrm{~h}$ starter cultures were centrifuged $(6000 \mathrm{rpm})$ for $5 \mathrm{~min}$, washed in $10 \mathrm{ml}$ of sterile distilled water and centrifuged again under the same conditions. After centrifugation, supernatant was decanted and pellets were re-suspended in distilled water to its original volume [9].

\section{Amaranth Substrate Preparation, Fermentation, and Storage}

Pseudocereal mashes were prepared from amaranth flour (Mlyn Zrno, Šišov, Slovakia). To maintain the same consistency, milk based mashes were prepared from $14 \%$ of amaranth flour, while the content of flour in water mashes was higher $(20 \%)$ with addition of $2 \%$ sucrose in both.

After boiling for $20 \mathrm{~min}$ and autoclaving at $121^{\circ} \mathrm{C}$ (20 $\mathrm{min}$ ) the mashes were cooled down and inoculated with the starter culture of selected strains of lactobacilli to achieve approximately initial number of $10^{3} \mathrm{CFU} \cdot \mathrm{ml}^{-1}$.

In case of co-cultivation, amaranth mashes were inoculated with starter Fresco DVS 1010 culture and Lactobacillus rhamnosus GG to achieve approximately
$10^{5}$ to $10^{6}$ CFU. $\mathrm{ml}^{-1}$. Static fermentations were performed for 14 hours at $37 \pm 1{ }^{\circ} \mathrm{C}\left(5 \% \mathrm{CO}_{2}\right)$ and were carried out in duplicate trials. The samples for analyses of counts and $\mathrm{pH}$ values were measured every 2 hours. After $8 \mathrm{~h}$ of co-cultivation pseudocereal amaranth mashes were carried out and stored at $6 \pm 1$ ${ }^{\circ} \mathrm{C}$ for 14 days.

\section{Viable Cell Enumeration}

Viable counts of lactobacilli were determined using ten-fold dilutions on Vegiton MRS agar plates (SigmaAldrich Chemie $\mathrm{GmbH}$, Switzerland) and counts of cocci from Fresco DVS 1010 culture on M17 agar plates (Biokar Diagnostics, Beauvais, France) in accordance with ISO 15214 [10]. Inoculated Petri dishes with lactobacilli were cultivated at $37 \pm 1{ }^{\circ} \mathrm{C}(5$ $\% \mathrm{CO}_{2}$ ) for 48 hours and mesophilic Fresco culture at aerobic conditions for 24 hours $\left(30 \pm 1^{\circ} \mathrm{C}\right)$.

\section{Evaluation of Growth and pH Values}

Growth parameters of lactic acid bacteria in amaranth mashes were fitted and calculated using the mechanistic model DMFit by Baranyi and Roberts (1994) [11]. Growth and metabolic parameters were calculated from each growth curve. Specific growth rates $(\mu)$ were recalculated from the growth rates $(g)$ according the equation $\mu=\ln 10 \times g$.

The $\mathrm{pH}$ levels were measured during fermentation and storage using a $\mathrm{pH}$ meter with a penetration electrode (Knick Portamess, Berlin, Germany).

\section{Statistical Analysis}

Specific growth rates of 4 tested lactobacilli strains were statistically evaluated using the Analyse-it Method Validation package ver. 3.50 (Analyse-it Software, Leeds, United Kingdom). Obtained growth rates of 4 tested lactic acid bacteria were analysed using Microsoft Excel 2010 (Microsoft, Redmond, Washington, USA). The data were treated by Student ttest with the least significant difference of $95 \%$.

\section{RESULTS AND DISCUSSION}

The aim of this study was to determine and compare the growth characteristics of probiotic and potentially probiotic strains in amaranth milk or water based mashes with sucrose. The growth and acidity curves of tested strain Lactobacillus rhamnosus GG are shown in Figure $\mathbf{1}$ and all calculated growth parameters of observed strains are summarized in Table 1. All strains investigated, attained high cell 


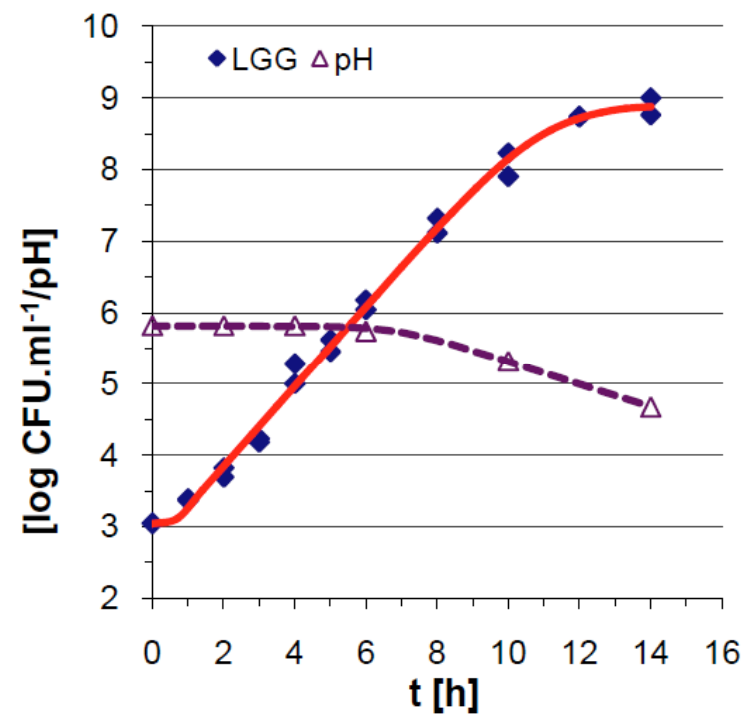

(a)

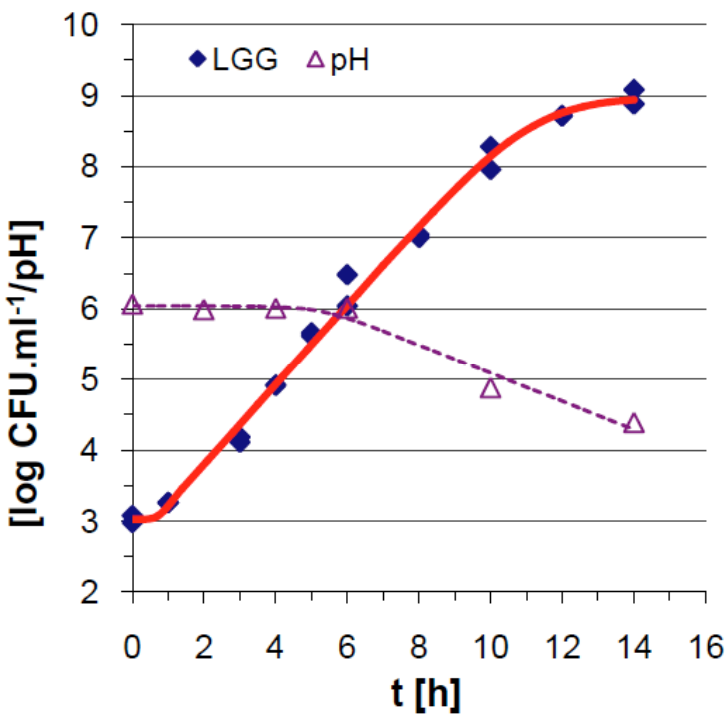

(b)

Figure 1: Growth dynamics and acidity changes of $L b$. rhamnosus GG in milk based-amaranth (a) and water based-amaranth (b) mash during fermentation at $37 \pm 1{ }^{\circ} \mathrm{C}$.

populations when growing in amaranth mashes at optimal temperature $37 \pm 1{ }^{\circ} \mathrm{C}$, reaching maximum densities of $10^{7}-10^{8} \mathrm{CFU} \cdot \mathrm{ml}^{-1}$ from initial $10^{3} \mathrm{CFU} \cdot \mathrm{ml}^{-1}$ in 14 hours. Helland et al. (2004) [6] evaluated growth dynamics of Lactobacillus rhamnosus GG in mashes prepared by combining rice and maize flour that after $12 \mathrm{~h}$ of fermentation at $37^{\circ} \mathrm{C}$ observed densities varied from $10^{8}$ to $10^{9} \mathrm{CFU} \cdot \mathrm{g}^{-1}$.

Salmerón et al. (2014) [12] evaluated growth of $L b$. plantarum in non-dairy cereal beverages during fermentation at $37^{\circ} \mathrm{C}$ for $10 \mathrm{~h}$. The highest density of observed strain was evaluated in the oat and barley media $\left(\mathrm{N}_{0}=8.2 \mathrm{log} \mathrm{CFU} \cdot \mathrm{ml}^{-1}\right.$ and $\mathrm{N}_{\mathrm{B}}=7.9 \mathrm{log}$ $\left.\mathrm{CFU} \cdot \mathrm{ml}^{-1}\right)$, respectively.

Both amaranth mashes were suitable for the growth of lactobacilli when growth rates in milk mashes ranged from 0.76 to $1.43 \mathrm{~h}^{-1}$ and in water based mashes from 0.73 to $1.52 \mathrm{~h}^{-1}$. Despite the claim that lactobacilli require for their growth complex nutrients such as carbohydrates, amino acids, peptides, vitamins, especially those of $B$ group and minerals present more in milk, the growth rates in milk amaranth mashes were similar to those in water. This fact was confirmed also in the study by Pelikánová et al. (2011a) [5].

In both mashes, Lb. rhamnosus VT1 entered immediately into the exponential phase of growth and showed the highest specific growth rates of all tested strains. In milk mash, growth rate of strain VT1 was characterized about $6 \%$ slower than in water product $\left(\mu=1.52 \mathrm{~h}^{-1}\right)$. No important difference between the growth rates of probiotic strain $L b$. rhamnosus $G G$ in amaranth milk and water mash $\left(1.29 \mathrm{~h}^{-1}\right.$ and $\left.1.30 \mathrm{~h}^{-1}\right)$ was determined, respectively.

Farnworth et al. (2007) [13] also reported Lb. rhamnosus GG reaching density higher than $10^{8}$ CFU. $\mathrm{ml}^{-1}$ in soy beverage at $41 \pm 1{ }^{\circ} \mathrm{C} / 12 \mathrm{~h}$ what was finally evaluated as better in comparison with milk $(2 \%$ fat).

For the strain $L b$. acidophilus 145, the greatest difference in growth between milk and water amaranth mash $(18 \%)$ was recorded. The lowest growth rate was calculated in case of $L b$. paracasei subsp. paracasei 1753 in water product $\left(0.73 \mathrm{~h}^{-1}\right)$. Kask et al. (2003) [14] evaluated maximal specific growth rate of Lb. paracasei in MRS broth, that ranged from 0,40 to $0,57 \mathrm{~h}^{-1}$. For this strain, growth rate in milk amaranth mash compared to UHT milk (1.5\% fat content) was about $39 \%$ higher [15]. Amaranth is a good source of proteins, amino acids, minerals and vitamins [16]. This fact indicates that the composition of flour promotes the growth of $L b$. paracasei subsp. paracasei 1753.

Presented results show changes in $\mathrm{pH}$ during a fermentation period of $14 \mathrm{~h}$, when final $\mathrm{pH}$ ranged between 5.52 - 4.39 in water mashes that was comparable to milk mashes $(5.73-4.67)$. Pelikánová et al. (2011a) [5] recorded changes of pH levels in amaranth substrates at $1.0-1.5$ units depended on the strain used. Martensson et al. (2002) [17] reported $\mathrm{pH}$ $3.9-4.5$ after fermentation (16 h) of an oat base product with commercial mixed dairy cultures. 
Table 1: Growth Parameters of Tested Lactobacilli in Amaranth Mashes, $14 \mathrm{~h}$ Fermentation at $37 \pm 1{ }^{\circ} \mathrm{C}$

\begin{tabular}{|c|c|c|c|c|}
\hline Substrate & Microorganism & $\mu\left[h^{-1}\right]$ & $\begin{array}{c}\lambda \\
{[\mathrm{h}]}\end{array}$ & $\begin{array}{c}\mathbf{k}_{\mathrm{pH}} \\
{\left[\mathrm{h}^{-1}\right]}\end{array}$ \\
\hline \multirow{4}{*}{ 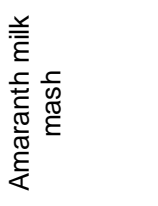 } & Lb. acidophilus 145 & $1.03^{\mathrm{a}}$ & 0.58 & -0.20 \\
\hline & Lb. rhamnosus GG & $1.29^{c}$ & 0.57 & -0.16 \\
\hline & Lb. rhamnosus VT1 & $1.43^{d}$ & - & -0.20 \\
\hline & Lb. paracasei subsp. paracasei 1753 & $0.76^{\mathrm{e}}$ & - & -0.10 \\
\hline \multirow{4}{*}{ 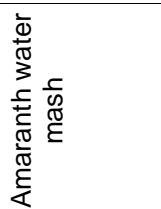 } & Lb. acidophilus 145 & $0.84^{b}$ & 2.09 & -0.04 \\
\hline & Lb. rhamnosus GG & $1.30^{c}$ & 0.63 & -0.20 \\
\hline & Lb. rhamnosus VT1 & $1.52^{d}$ & - & -0.21 \\
\hline & Lb. paracasei subsp. paracasei 1753 & $0.73^{\mathrm{e}}$ & 2.99 & -0.17 \\
\hline
\end{tabular}

$\mu$ - specific growth rate, $\lambda$ - lag-phase duration, $\mathrm{k}_{\mathrm{pH}}$ - rate constant for the decrease of $\mathrm{pH}$; the same letters in the superscript indicate that three Lactobacillus spp. ${ }^{(c, d, e)}$ did not showed any differences at the $0.5 \%$ significance level between the specific growth rates in the water- and milk-based mashes

The $\mathrm{pH}$ levels of final products depended not only on the strain used but also on the composition of mash (milk/water). Due to lower buffering capacity of the water-based mashes, reduction in $\mathrm{pH}$ was faster in comparison with milk-based mashes except probiotic strain Lb. acidophilus 145. Amaral Santos et al. (2014) [18] observed a rapid drop of $\mathrm{pH}$ value in peanut-soy milk substrate fermented only by $L b$. acidophilus (LACA 4), reaching $\mathrm{pH}$ value 4.6 at $12 \mathrm{~h}$ of fermentation. Determined limited $\mathrm{pH}$ value for survival of probiotic strain $L b$. acidophilus ranged from 3.4 to 3.6 depending on type of substrate used [19].

The highest rate of $\mathrm{pH}$ decrease was found in case of $L b$. rhamnosus VT1 $\left(-0.21 \mathrm{~h}^{-1}\right)$ while the lowest final

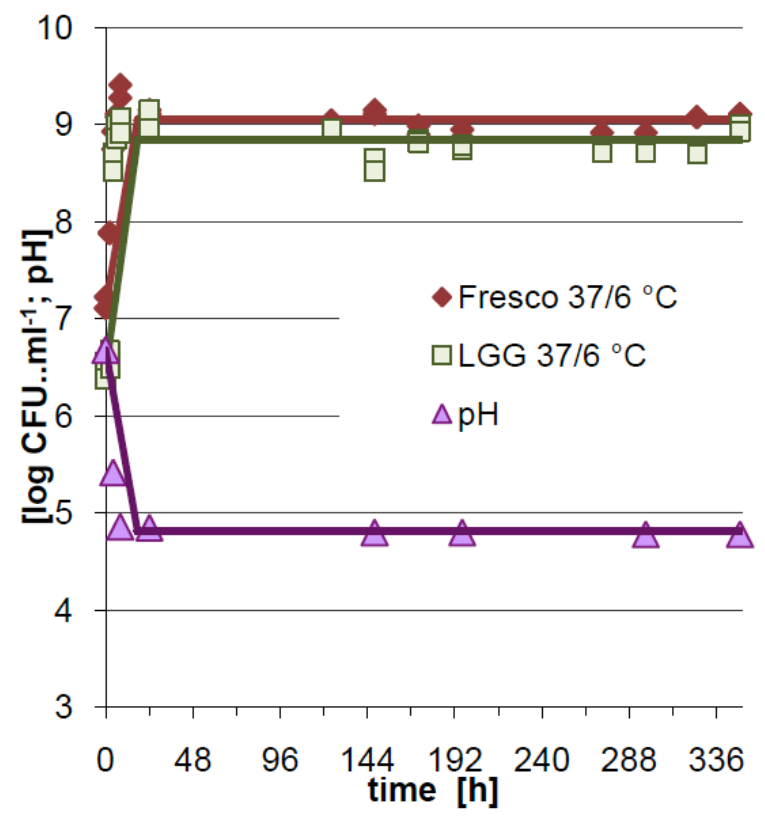

(a)
$\mathrm{pH}$ value of 4.39 was recorded in water amaranth mash fermented by $L b$. rhamnosus GG. On the other hand, [20] determined the final $\mathrm{pH}$ of 4.9 in milk (1.5\% fat) fermented by $L b$. rhamnosus $G G$ after $10 \mathrm{~h}$ of fermentation process.

Kocková and Valík (2014) and Pelikánová et al., (2015) [21, 22] evaluated growth dynamic of $L b$. rhamnosus GG in cereal and pseudocereal flours. Population density reached counts $10^{7}$ to $10^{8} \mathrm{CFU} . \mathrm{g}^{-1}$ at the end of $10 \mathrm{~h}$ fermentation process $\left(37 \pm 1^{\circ} \mathrm{C}\right)$. Sterr et al. (2009) [23] have noticed the change of $L b$. plantarum about 1 to $3 \log$ CFU.ml ${ }^{-1}$ in pseudocereal product prepared form buckwheat flour to final densities $\left(10^{8}-10^{10} \mathrm{KTJ} . \mathrm{g}^{-1}\right)$. In our case during $8 \mathrm{~h}$ of

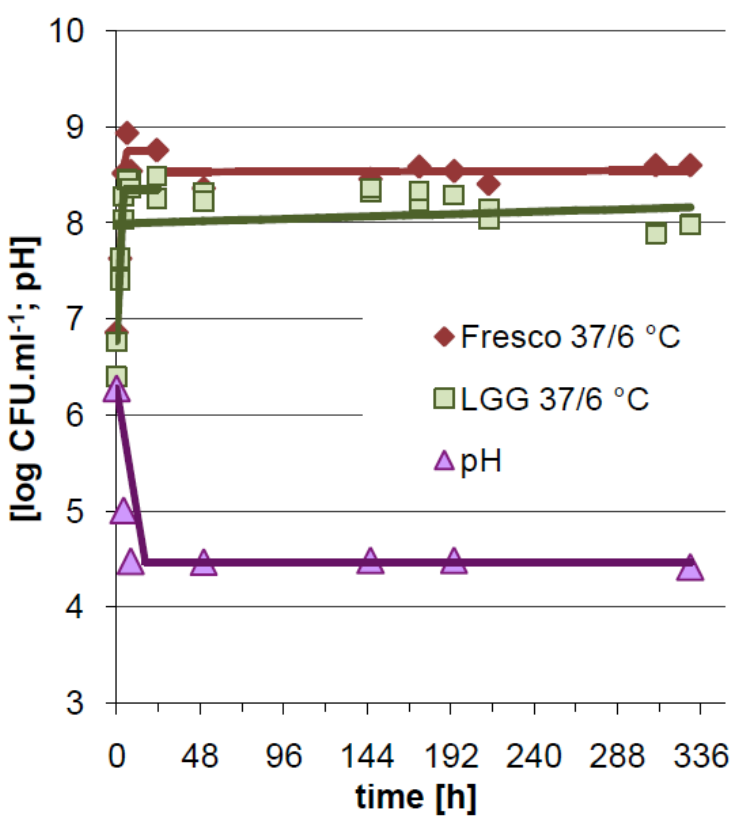

(b)

Figure 2: Evaluation of cell counts of Fresco DVS 1010 culture and $L b$. rhamnosus GG in milk based-amaranth (a) and water based-amaranth (b) mashes during fermentation at $37 \pm 1{ }^{\circ} \mathrm{C}$ and cold storage at $6 \pm 1{ }^{\circ} \mathrm{C}$. 
Table 2: Growth Parameters of Lb. rhamnosus GG and Cocci from Fresco DVS 1010 Culture During $8 \mathrm{~h}$ of CoCultivation at $37 \pm 1{ }^{\circ} \mathrm{C}$ in Amaranth Mashes

\begin{tabular}{|c|c|c|c|c|}
\hline \multirow{2}{*}{ Substrate } & Microorganism & $\begin{array}{c}\boldsymbol{\mu}_{\mathrm{f}} \\
{\left[\mathbf{h}^{-1}\right]}\end{array}$ & $\begin{array}{c}\boldsymbol{\lambda} \\
{[\mathrm{h}]}\end{array}$ & $\begin{array}{c}\mathbf{k}_{\mathrm{pH}} \\
{\left[\mathbf{h}^{-1}\right]}\end{array}$ \\
\hline \hline \multirow{2}{*}{$\begin{array}{c}\text { Amaranth } \\
\text { milk mash }\end{array}$} & Fresco DVS 1010 & 0.98 & - & -0.32 \\
\cline { 2 - 4 } & Lb. rhamnosus GG & 2.91 & - & \\
\cline { 1 - 3 } Amaranth water mash & Fresco DVS 1010 & 0.99 & - & \multirow{2}{*}{-0.32} \\
\cline { 2 - 4 } & Lb. rhamnosus GG & 0.99 & -21 & \\
\hline
\end{tabular}

$\left(\mu_{\mathrm{f}}\right.$ - specific growth rate in co-culture with Fresco culture, $\lambda$ - lag phase, $\mathrm{k}_{\mathrm{pH}}-$ rate constant for the decrease of $\left.\mathrm{pH}\right)$.

co-cultivation, $L b$. rhamnosus $G G$ was able to grow from initial counts $\mathrm{N}_{0}=10^{6}$ to $10^{7} \mathrm{CFU} \cdot \mathrm{ml}^{-1}$ to final $\mathrm{N}_{\text {end }}$ $=10^{8}$ to $10^{9} \mathrm{CFU} \cdot \mathrm{ml}^{-1}$ that was similar to density of Fresco DVS 1010 reached in both mashes (Figure 2).

An overview of growth parameters of studied strains in water and milk based mashes is summarized in Table 2.

Rathore et al. (2012) [24] observed rapid growth of $L$ b. plantarum in single malt, barley and barley-malt (mixed) substrates at $30^{\circ} \mathrm{C}$ for $28 \mathrm{~h}$ at the beginning of fermentation ( $6 \mathrm{~h})$. On the other hand, Leponen et al. (2007) [25] confirmed also in oat brans that lactic acid bacteria with dominance of Lactobacillus rhamnosus reached $10 \log \mathrm{CFU} \cdot \mathrm{g}^{-1}$ at $37^{\circ} \mathrm{C}$ after $12-\mathrm{h}$.

The addition of milk had no positive impact on the growth rates of Fresco DVS 1010 culture, that grew at about the same in the amaranth mash based on milk ( $\mu$ $\left.=0.98 \mathrm{~h}^{-1}\right)$ and water $\left(\mu=0.99 \mathrm{~h}^{-1}\right)$, despite of higher content of specific nutrients in milk. Fresco culture entered directly after the beginning of fermentation into the exponential phase of growth. Only in case of milk based mash, lag phase of $L b$. rhamnosus $G G$ was observed $(2.21 \mathrm{~h})$.

The highest growth rate of lactobacilli was calculated in milk mash $\left(\mu=2.91 \mathrm{~h}^{-1}\right)$ which was characterized about $66 \%$ higher than in water product. Viable counts of cocci from Fresco DVS 1010 and probiotic strain $L b$. rhamnosus $G G$ after 14 days at $6 \pm$ $1{ }^{\circ} \mathrm{C}$ were not reduced and were similar to those reached after the fermentation process $\left(10^{8}\right.$ to $10^{9}$ CFU. $\mathrm{ml}^{-1}$ ). Thus, density of $L b$. rhamnosus $\mathrm{GG}$ after 14 days of storage was over the limit required for probiotic food $>10^{6} \mathrm{CFU} \mathrm{ml}^{-1}\left(\mathrm{CFU} \cdot \mathrm{g}^{-1}\right)$. Shah et al. (1995) [26] observed only a slight decrease of counts of probiotic strain $L b$. acidophilus 145 in curdled milk at $6{ }^{\circ} \mathrm{C}$ during 21 days of storage. Pelikánová et al. (2011a) [5] confirmed the ability of probiotic strain $L b$. rhamnosus GG to survive in amaranth mashes for 21 days during cold storage at $6{ }^{\circ} \mathrm{C}$.
Calculated rates of reducing $\mathrm{pH}$ were the same ($\left.0.32 \mathrm{~h}^{-1}\right)$ in milk and water mash. At the end of $14 \mathrm{~d}$ cold storage in water mash, final $\mathrm{pH}$ level (4.42) dropped from initial 6.28 in milk fermented mash to final 4.86 .

\section{CONCLUSION}

Our results pointed out that all four tested strains of lactobacilli showed good growth in milk and water amaranth products. In fermentation of amaranth substrates by 4 LAB strains, no statistically significant differences in impact of water or milk environment were observed, except probiotic strain Lactobacillus acidophilus 145.

The milk base of mashes proved to be a better substrate for growth of microbial strains $L b$. paracasei subsp. paracasei 1753 and Lb. acidophilus 145 . Potentially probiotic strain $L b$. rhamnosus VT1 and probiotic strain $L b$. rhamnosus $G G$ showed the highest specific growth rates in water-based mashes. Overall, strain Lb. rhamnosus VT1 showed the highest growth rates in all types of substrates and it showed the fastest decrease in $\mathrm{pH}$ values. We also evaluated densities of probiotic strain $L b$. rhamnosus $G G$ during 14 days storage period. Based on the microbiological results obtained, probiotic mashes may be beneficial for consumers, if they are sensory accepted.

Such development of new non-dairy foods containing probiotics may lead to enrichment of product range suitable for handicapped consumers - people suffering from lactose intolerance, allergy to milk proteins or people on low protein diet because of the restriction in consumption of dairy products.

\section{ACKNOWLEDGEMENT}

This work was financially supported by The Scientific Grant Agency of the Ministry of Education of Slovak Republic VEGA no. 1/0495/13. 


\section{REFERENCES}

[1] Chakoosari MMD, Ghasemi MF, Masiha A. Antimicrobial activities of lactic acid bacteria. Bulletin of Environment, Pharmacology and Life Sciences 2014; 3: 275-278.

[2] Marko A, Rakická M, Mikušová L, Valík L', Šturdík E. Lactic acid fermentation of cereal substrates in nutritional perspective. International Journal of Research in Chemistry and Environment 2014; 4: 80-92.

[3] Vasudha S, Mishra HN. Non dairy probiotic beverages. International Food Research Journal 2013; 1:7-15.

[4] Charalampopoulos D, Wang R, Pandiella SS, Webb C. Application of cereals and cereal components in functional foods: a review. International Journal of Food Microbiology 2002; 79: 131-141.

http://dx.doi.org/10.1016/S0168-1605(02)00187-3

[5] Pelikánová J, Liptáková D, Valík L', Stančeková K. Evaluation of the growth of selected lactobacilli in pseudocereal substrate. Potravinárstvo 2011a; 5: 53-57. http://dx.doi.org/10.5219/169

[6] Helland $\mathrm{MH}$, Wicklund T, Narvhus JA. Growth and metabolism of selected strains of probiotic bacteria in milkand water-based cereal puddings. International Dairy Journal 2004; 14: 957-965.

http://dx.doi.org/10.1016/.j.idairyj.2004.03.008

[7] Blandino A, Al-Aseeri ME, Pandiella SS, Cantero D, Webb C. Cereal-based fermented foods and beverages. Food Research International 2003; 36: 527-543. http://dx.doi.org/10.1016/S0963-9969(03)00009-7

[8] Kocková M, Dilongová M, Hybenová E, Valík L'. Evaluation of Cereals and Pseudocereals Suitability for the Development of New Probiotic Foods. Journal of Chemistry 2013; 1-8. http://dx.doi.org/10.1155/2013/414303

[9] Angelov A, Gotcheva V, Kuncheva R, Hristozova T. Development of a new oat-based probiotic drink. International Journal of Food Microbiology 2006; 112: 75-80. http://dx.doi.org/10.1016/j.ijfoodmicro.2006.05.015

[10] STN ISO 15214. Microbiology of food and animal feeding stuff: Horizontal method for enumeration of mesophilic lactic acid bacteria. Colony count technique 2002.

[11] Baranyi J, Roberts TA. Mathematics of predictive food microbiology. Journal of Food Microbiology 1994; 26: 199218.

http://dx.doi.org/10.1016/0168-1605(94)00121-L

[12] Salmerón I, Thomas K, Pandiella SS. Effect of substrate composition and inoculum on the fermentation kinetics and flavor compound profiles of potentially non-dairy probiotic formulations. LWT - Food Science and Technology 2014; 55: 240-247.

http://dx.doi.org/10.1016/j.Iwt.2013.07.008

[13] Farnworth ER, Mainville I, Desjardins MP, Gardner N, Fliss I, Champagne C. Growth of probiotic bacteria and bifidobacteria in a soy yogurt formulation. International Journal of Food Microbiology 2007; 116: 174-181. http://dx.doi.org/10.1016/j.ijfoodmicro.2006.12.015
[14] Kask S, Adamberg K., Orlowski A, Vogensen FK, Møller PL, Ardö Y, Paalme T. Physiological properties of Lactobacillus paracasei, $L$. danicus and $L$. curvatus strains isolated form Estonian semihard cheese. Food Research International 2003; 36: 1037-1046.

http://dx.doi.org/10.1016/j.foodres.2003.08.002

[15] Pelikánová J, Liptáková D, Valík L'. The growth dynamics of Lactobacillus paracasei in milk. Potravinárstvo 2011b; 5: 5357.

[16] Moroni AV, Arendt EK, BelloFD. Biodiversity of lactic acid bacteria and yeasts in spontaneously-fermented buckwheat and teff sourdoughs. Food Microbiology 2011; 28: 497-502. http://dx.doi.org/10.1016/i.fm.2010.10.016

[17] Martensson O, Staaf J, Duecas-Chasco M, Irastorza A, Oste $\mathrm{R}$, Holst $\mathrm{O}$. A fermented, ropy, non-dairy oat product based on the exopolysaccharide-producing strain Pediococcus damnosus. Advances in Food Sciences 2002; 24: 4-11.

[18] Amaral Santos CCA, Libeck BS, Schwan RB. Co-culture fermentation of peanut-soy milk for the development of a novel functional beverage. International Journal of Food Microbiology 2014; 186: 32-41.

http://dx.doi.org/10.1016/j.ijfoodmicro.2014.06.011

[19] Lönner C, Akesson PK. Acidification properties of lactic acid bacteria in rye sour doughs. Food Microbiology 1988; 5: 4358.

http://dx.doi.org/10.1016/0740-0020(88)90007-X

[20] Østlie HM, Helland MH, Narvhus JA. Growth and metabolism of selected strains of probiotic bacteria in milk. International Journal of Food Microbiology 2003; 87: 17-27. http://dx.doi.org/10.1016/S0168-1605(03)00044-8

[21] Kocková M, Valík L'. Development of new cereal-, pseudocereal-, and cereal-leguminous-based probiotic foods. Czech Journal of Food Science 2014; 32: 391-397.

[22] Pelikánová J, Liptáková D, Valík L'. The siutability of the lactic acid bacteria for fermentation of maize and amaranth Journal of Food and Nutrition Research 2015; In Press.

[23] Sterr $\mathrm{Y}$, Weiss A, Schmidt H. Evaluation of lactic acid bacteria for sourdough fermentation of amaranth International Journal of Food Microbiology 2009; 136: 75-82. http://dx.doi.org/10.1016/j.ijfoodmicro.2009.09.006

[24] Rathore S, Salmerón I, Pandiella SS. Production of potentially probiotic beverages using single and mixed cereal substrates fermented with lactic acid bacteria cultures. Food Microbiology 2012; 30: 239-244. http://dx.doi.org/10.1016/i.fm.2011.09.001

[25] Leponen J, Laine $P$, Sontag-Strohm T, Salovaara $H$. Behaviour of oat globulins in lactic acid fermentation of oat bran. European Food Research and Technology 2007; 225: 105-110. http://dx.doi.org/10.1007/s00217-006-0387-9

[26] Shah NP, Lankaputhra WEV, Britz ML, Kyle WSA. Survival of Lactobacillus acidophilus and Bifidobacterium bifidum in commercial yoghurt during refrigerated storage. International Dairy Journal 1995; 5: 515-521. http://dx.doi.org/10.1016/0958-6946(95)00028-2 